\title{
FUNGSI NASKAH AKADEMIK DALAM PEMBENTUKAN PERATURAN PERUNDANG-UNDANGAN
}

\author{
MUHSIN \\ Dosen Hukum Tata Negara Fakultas Hukum Universitas Islam Indragiri \\ E_mail : $\underline{\text { uchein.inhil@gmail.com }}$
}

\begin{abstract}
Naskah akademik adalah naskah hasil penelitian atau pengkajian hukum dan hasil penelitian lainnya terhadap suatu masalah tertentu yang dapat dipertanggungjawabkan secara ilmiah mengenai pengaturan masalah tersebut dalam suatu Rancangan Undang-Undang, Rancangan Peraturan Daerah Provinsi, atau Rancangan Peraturan Daerah Kabupaten/Kota sebagai solusi terhadap permasalahan dan kebutuhan hukum masyarakat Peraturan perundang-undangan. Adapun permasalahan yang dibahas dalam penelitian ini adalah bagaimana latar belakang diperlukannya naskah akademik dalam pembentukan peraturan perundang-undangan dan bagaimana fungsi naskah akademik dalam pembentukan peraturan perundangundangan.Metode penelitian ini tergolong dalam penelitian hukum normatif atau penelitian kepustakaan ( Library riseach yaitu pendekatan yang menggunakan konsep legis positivis yang menyatakan bahwa hukum adalah identik dengan norma-norma tertulis yang dibuat dan diundangkan oleh lembaga-lembaga atau pejabat berwenang. Kesimpulan Latar belakang diperlukannya naskah akademik dalam pembentukan peraturan perundang-undangan adalah demi tercapainya cita-cita hukum, demi terwujudnya asas-asas pembentukan perundang-undangan yang baik, efektivitas peraturan perundang-undangan, agar peraturan tidak di uji materiil, dan karena naskah akademik merupakan bagian dari pembentukan peraturan perundangundangan. Fungsi naskah akademik adalah sebagai naskah ilmiah yang dapat dipertanggungjawabkan yang berisi latar belakang, tujuan penyusunan, sasaran yang ingin diwujudkan, memberikan gambaran mengenai substansi, materi dan ruang lingkup dari sebuah peraturan perundang-undangan yang akan dibuat, dan memberikan pertimbangan dalam rangka pengambilan keputusan bagi pihak.
\end{abstract}

\section{Kata kunci: Fungsi Naskah Akademik}

\begin{abstract}
Academic manuscripts are the results of research or legal studies and other research results on a particular problem that can be scientifically justified regarding the regulation of the problem in a Draft Law, Draft Provincial Regulation, or Draft Regency/City Regional Regulation as a solution to problems and the legal needs of the community. Legislation. The problems discussed in this study are how the background of the need for academic texts in the formation of legislation and how the function of academic texts in the formation of laws and regulations. This research method belongs to normative legal research or library research (Library research, namely an approach that uses the positivist legis concept which states that law is identical with written norms made and promulgated by authorized institutions or officials Conclusion The background of the need for academic texts in the formation of legislation is to achieve
\end{abstract}


legal ideals, for the realization of the principles of the principle of the formation of good legislation, the effectiveness of laws and regulations, so that the regulations are not tested materially, and because academic texts are part of the formation of laws and regulations. can be accounted for which contains the background, objectives of the preparation, targets to be realized, provides an overview of the substance, material and scope of a statutory regulation that will be made, and provides considerations in the context of making decisions for parties.

\section{Keywords: Academic Paper Function Akademi}

\section{PENDAHULUAN}

\section{A. Latar Belakang}

Negara hukum (Rechtstaat atau Rule of Law) adalah konsep negara yang diidealkan oleh para pendiri bangsa yang membahas dan merumuskan UUD 1945, sebagaimana kemudian dituangkan dalam penjelasan UUD 1945 sebelum perubahan. Penegasan sebagai negara hukum dikuatkan dalam UUD 1945 setelah perubahan Pasal 1 ayat (3) yang berbunyi "Negara Indonesia adalah Negara Hukum". 1

Dalam setiap negara hukum, dipersyaratkan berlakunya asas legalitas dalam segala bentuknya (due process of law), yaitu bahwa segala tindakan pemerintahan harus didasarkan atas peraturan perundang-undangan yang sah dan tertulis. Peraturan perundang-undangan tertulis tersebut harus ada dan berlaku lebih dulu atau mendahului tindakan atau perbuatan administrasi yang dilakukan. Dengan demikian, setiap perbuatan atau tindakan administrasi harus didasarkan atas aturan atau "rules and procedures" (regels). ${ }^{2}$

Peraturan perundang-undangan sebagai produk hukum dibuat dengan maksud untuk dipatuhi oleh masyarakat atau dengan kata lain untuk efektif atau hukum tersebut berperan sesuai fungsinya. Soerjono Soekanto mengatakan bahwa untuk dapat mewujudkan fungsi dari perundang-undangan maka ada 3 (tiga) kriteria yang harus dipenuhi:

1. Bila hukum hanya berlaku secara yuridis maka kemungkinan besar kaidahnya hanya merupakan kaidah yang mati (dode regel).

2. Jika hukum hanya berlaku secara sosiologis maka mungkin hukum berlaku sebagai hanya sebagai aturan pemaksa.

3. Jika hukum hanya berlaku secara filosofis maka mungkin hukum itu hanya akan menjadi hukum yang dicita-citakan.

Istilah peraturan perundang-undangan (wettelijke regeling), apabila dikaitkan dengan pembentukan peraturan perundang-undangan negara, menurut Burkhardt Krems dengan menggunakan istilah (staatsliche rechtssetzung), adalah untuk menentukan isi peraturan (inhalt der legelung), bentuk dan susunan peraturan (form der regelung), metode pembentukan peraturan (methode der ausarbeitung der

${ }^{1}$ Jimly Asshidiqie (I), Implikasi Perubahan UUD 1945 Terhadap Pembangunan Hukum Nasional, (Jakarta, Mahkamah Konstitusi Republik Indonesia, 2005) Hal.21.

2 Jimly Asshidiqie (III), Konstitusi dan Konstitusionalisme (Jakarta: Konstitusi Pers, 2005) Hal. 124 
regeling), prosedur dan proses pembentukan peraturan (verfahren der ausarbeitung der regelung). ${ }^{3}$

Proses perundang-undangan bisa dilihat dari dua perspektif, yakni perspektif normatif yuridis dan perspektif sosiologis.8 Dari perspektif normatif yuridis proses yang dilakukan tidak lain adalah menyangkut perumusan, pembahasan dan pengundangan suatu peraturan perundang-undangan. ${ }^{4}$ Dari perspektif sosiologis empirik proses yang dilakukan adalah dengan cara abstraksi, yakni mencari unsurunsur yuridis dari gejala sosial kemasyarakatan yang kemudian dituangkan dalam rumusan hukum yang sifatnya tertulis. Dalam proses abstraksi inilah penyusunan naskah akademik dari suatu peraturan perundang-undangan menjadi sangat penting artinya. $^{5}$

Naskah Akademik adalah naskah hasil penelitian atau pengkajian hukum dan hasil penelitian lainnya terhadap suatu masalah tertentu yang dapat dipertanggungjawabkan secara ilmiah mengenai pengaturan masalah tersebut dalam suatu Rancangan Undang-Undang, Rancangan Peraturan Daerah Provinsi, atau Rancangan Peraturan Daerah Kabupaten/Kota sebagai solusi terhadap permasalahan dan kebutuhan hukum masyarakat. ${ }^{6}$

Mempersiapkan naskah akademik merupakan salah satu langkah penting dalam rangka legislasi, karena naskah akademik berperan sebagai quality control yang sangat menentukan kualitas suatu produk hukum. Naskah akademik memuat seluruh informasi yang diperlukan untuk mengetahui landasan pembuatan suatu peraturan perundang-undangan baru, termasuk tujuan dan isinya. ${ }^{7}$

Naskah akademik merupakan salah satu landasan dan sekaligus arah penyusuan suatu peraturan perundang-undangan. Pembuat peraturan perundangundangan hendaknya mempertimbangkan besarnya upaya yang perlu dicurahkan dalam membuat suatu naskah akademik. Terdapat beberapa alasan kuat mengapa manyusun naskah akademik membutuhkan alokasi waktu dan daya upaya. Waktu dan upaya yang memadai memberikan kesempatan bagi pembentuk peraturan perundang-undangan untuk melakukan penelitian dan menganalisis masalah, melebihi apa yang diperlukan bagi suatu produk hukum baru. Hal yang demikian menghasilkan peningkatan kapasitas aparat maupun instansi yang nantinya menangani program yang akan dihasilkannya. Dalam mempertimbangkan cara menyusun suatu naskah akademik yang bagus, pembuat peraturan perundang-

${ }^{3}$ Yuliandri, Asas-Asas Pembentukan Peraturan Perundang-Undangan Yang Baik, (Jakarta, : PT. Raja Grafindo Persada, 2009), Hal 37

${ }^{4}$ Ibid Hal. 18

${ }^{5}$ Ibid Hal 19

${ }^{6}$ Undang-Undang Nomor 12 tahun 2011 Tentang Pembentukan Peraturan Perundang-Undangan Pasal 1 angka 11

12 Yuliandri,Op.Cit.

${ }^{7}$ Ibid. hal. 143 
undangan hendaknya substansi dan proses penyusunan naskah akademik yang akan dibuat. $^{8}$

Sebuah naskah akademik harus menelaah tiga permasalahan substansi, yaitu: Pertama, mampu menjawab pertanyaan mengapa diperlukan peraturan baru; Kedua, lingkup materi kandungan dan komponen utama peraturan; dan Ketiga, proses yang akan digunakan untuk menyusun dan mengesahkan peraturan. ${ }^{9}$

Oleh karena itu, sudah seharusnya setiap norma hukum yang akan dituangkan dalam bentuk rancangan undang-undang, benar-benar telah disusun berdasarkan pemikiran yang matang dan perenungan yang mendalam, semata-mata untuk kepentingan umum (public interest), bukan kepentingan pribadi atau golongan. ${ }^{10}$

Banyak permasalahan yang tidak dapat diketahui dari awal, dalam hal pembentukan undang-undang tidak didahului dengan penyusunan naskah akademik. Kadang kala dapat terjadi, pembentukan undang-undang tidak memberikan jawaban terhadap berbagai permasalahan dalam masyarakat. Bahkan dapat terjadi, ketika suatu undang-undang telah dibentuk dan dinyatakan berlaku,Pentingnya naskah akademik dalam menyertai suartu rancangan peraturan perundang-undangan karena dalam naskah akademik itulah paradigma kehidupan kemasyarakatan yang hendak dituju oleh peraturan perundang-undangan yang dibentuk dirumuskan secara terperinci melalui pendekatan ilmiah. Lain daripada itu, keberadaan naskah akademik yang menyertai suatu rancangan peraturan perundang-undangan dapat juga dikatakan sebagai sumber inspirasi bagi rancangan peraturan perundangundangan yang akan diperjuangkan oleh pihak pemrakarsa agar memenuhi kriteria akademik, sehingga perdebatan mengenai materi muatan yang nantinya akan dituangkan ke dalam sebuah rancangan peraturan perundang-undangan dapat dieliminir seminim mungkin. ${ }^{11}$

Perlu disadari bahwa di dalam suatu negara yang masyarakatnya yang sangat pluralistis seperti Indonesia perlu ada semacam konsensus dan kompromi nasional melakukan pebagai tindakan yang berisi nilai-nilai di bidang politik, hukum, sosial, ekonomi dan budaya yang akan dituangkan kedalam peraturan perundang-undangan sebagai manifestasi nilai-nilai dasar, tidak jarang terjadi deal-deal politik yang kadang menyimpang dari esensi nilai-nilai dasar. ${ }^{12}$

Kondisi yang demikian ini makin diperparah, jikalau paradigma peraturan perundang-undangan (hukum) merupakan produk politik terlalu ditonjolkan dalam setiap proses pembentukan perturan perundang-undangan. Penonjolan yang membabi buta terhadap paradigma seperti ini akan mengakibatkan hukum

\footnotetext{
${ }^{8}$ Ibid Hal 144

${ }^{9}$ Ibid Hal 144

${ }^{10}$ Jimly Asshidiqie (IV), Perihal Undang-Undang di Indonesia, (Jakarta, : Sekretariat Jenderal dan Kepaniteraan Mahkamah Konstitusi RI, 2006).hal. 320.

${ }^{11}$ Ibid. Hal. 192

${ }^{12}$ H. A. S. Natabaya, Manifestasi Nilai-Nilai Dasar Dalam Peraturan Perundang-Undangan, Jurnal Konstitusi, (Volume 3 Nomor 2, Mei 2006), Mahkamah Konstitusi Republik Indonesia, 2006, hal. 8-20.
} 


\section{FUNGSI NASKAH AKADEMIK DALAM PEMBENTUKAN} PERATURAN PERUNDANG-UNDANGAN- Muhsin

(peraturan perundang-undangan) hanya dipergunakan sebagai alat politik, bukan alat menciptakan keadilan. ${ }^{13}$

Pengalaman selama ini menunjukkan bahwa ketika naskah akademik dan naskah perturan perundang-undangan sudah dibentuk oleh para perancang peraturan-perundang-undangan melalui serangkaian penelitian dan penelitian, maka setelah menjadi pembahasan, pada umumnya semua konsep itu menjadi tidak berlaku. 14

Berdasarkan rumusan dalam Pasal 3 dan Pasal 4 Keputusan Presiden Nomor 188 Tahun 1998 Tentang Tata Cara Mempersiapkan Rancangan Undang-Undang, Maria Farida Indrati Soeprapto menyatakan keberadaan suatu Naskah Akademik dalam pembentukan rancangan undang-undang belum merupakan suatu kewajiban. Selanjutnya dalam Peraturan Tata Tertib DPR RI Nomor 15/DPR RI/ 2004-2005 menyatakan keberadaan suatu naskah akademik perlu menjadi suatu pertimbangan. Suatu rancangan undang-undangan boleh diajukan dengan naskah akademik atau tanpa naskah akademik, asal rancangan undang-undang tersebut disertai dengan penjelasan dan keterangan. ${ }^{15}$

Ketentuan lain dalam Undang-Undang Nomor 12 Tahun 2011 tentang Pembentukan Peraturan Perundang-Undangan mengatur bahwa Peraturan Daerah Propinsi dan Peraturan Daerah Kota/Kabupaten dapat disertai dengan naskah akademik. Dalam hal ini naskah akademik kembali hanya menjadi sebuah alternatif saja dalam pembentukan peraturan perundang-undangan.Jika diperhatikan ketentuan yang ada dalam Peraturan Perundang-Undangan seperti :

a. Keputusan Presiden Nomor 188 Tahn 1998 Tentang Tata Cara Mempersiapkan Rancangan Undang-Undang;

b. Peraturan Presiden Nomor 68 Tahun 2005 Tentang Tata Cara Mempersiapkan Rancangan Undang-Undangan, Rancangan Peraturan Pemerintah Pengganti Undang-Undang, Rancangan Peraturan Pemerintah, Rancangan Peraturan Presiden, dan

c. Qanun Aceh Nomor 3 Tahun 2007 Tentang Tata Cara Pembentukan Qanun.

Keberadaan naskah akademik yang menyertai suatu rancangan peraturan perundang-undangan sifatnya adalah optional (tidak wajib). Mengingat dalam ketiga produk hukum tersebut ini sama-sama menggunakan kata „dapat". Hal ini berarti keberadaan suatu naskah akademik yang menyertai suatu rancangan undang-undang sifatnya hanya sebuah anjuran. ${ }^{16}$

\footnotetext{
13 Benediktus Hestu CiptoHandoyo, Prinsip-Prinsip Legal Drafting dan Naskah Akademik,(Yogyakarta, : Cahaya Atma Pustaka, 2014), Hal.14

${ }^{14}$ Ibid. Hal.58

${ }^{15}$ Maria Farida Indrati S, Ilmu Perundang-Undangan, Proses dan Teknik Pembentukannya, buku 2, (Yogyakarta :, kanisius, 2007), Hal. 240-255

${ }^{16}$ Rachmat Trijono, Dasar-Dasar Ilmu Pengetahuan Perundang-Undangan, ( Jakarta :, Papas Sinar Sinanti, 2013), Hal. 111
} 
Hal lain yang perlu mendapat perhatian adalah pedoman yang harus digunakan dalam membuat naskah akademik. Dalam lampiran Undang-Undang Nomor 12 Tahun 2011 tentang Pembentukan Peraturan Perundang-undangan memang mengatur tentang teknik penyusunan naskah akademik. Namun teknik penyusunan naskah akademik tersebut untuk undang-undangan dan peraturan daerah saja. Peraturan perundang-undangan yang lain tentu memerlukan pedoman dalam penyusunan naskah akademik. Pedoman pembuatan naskah akademik selain sebagai pegangan bagi legal drafter, juga berperan dalam mengarahkan terciptanya naskah akademik yang berkualitas demi tercapainya peraturan yang baik.

Adanya Naskah Akademik dalam tiap perancangan peraturan sangat penting untuk memberikan gambaran mengenai hasil penelitian ilmiah yang mendasari usulan rancangan setiap peraturan, yang kelak akan diajukan dan sekaligus memperlihatkan bahwa rancangan peraturan yang diusulkan bukan didasarkan pada kepentingan sesaat, kebutuhan yang mendadak, atau karena pemikiran yang tidak mendalam, tetapi harus jelas tujuan dan sasarannya.

Dilain pihak naskah akademik sangat dibutuhkan bagi para perancang peraturan-perundang-undangan (legal drafter), khususnya dalam rangka melakukan formulasi muatan materi yang hendak diatur kedalam suatu rancangan peraturan perundang-undangan yang dirumuskan. Kebutuhan akan naskah akademik tersebut sangat penting mengingat para perancang peraturan perundang-undangan yang pada umumnya adalah para ahli hukum, tentu tidak mengetahui pernik-pernik materi muatan yang akan dimuat dalam suatu rancangan peraturan perundang-undangan. ${ }^{17}$

Sehubungan dengan penjelasan singkat latar belakang di atas, peneliti mengangkat judul Fungsi Naskah Akademik Dalam Pembentukan Peraturan Perundang-Undangan sebagai penelitian dalam bantuk jurnal.

Bagian latar belakang mengurai mengenai hal-hal yang menjadi alasan-alasan sehingga dipandang penting sehingga dilakukannya penelitian, analisis/tinjauan putusan lembaga peradilan, kajian teori, studi kepustakaan atau gagasan kritis konseptual yang akan disajikan di dalam jurnal ini.

\section{B. Rumusan Masalah}

Berdasarkan latar belakang di atas, maka dalam penelitian ini penulis merumuskan permasalahan yang akan diteliti yaitu:

1. Bagaimana latar belakang naskah akademik diperlukan dalam pembentukan peraturan perundang-undangan?

2. Bagaimana fungsi naskah akademik dalam pembentukan peraturan perundangundangan?

\section{Metode Penelitian}

Jenis penelitian yang dilakukan adalah penelitian yuridis normatif yaitu pendekatan yang menggunakan konsep legis positivis yang menyatakan bahwa

\footnotetext{
${ }^{17}$ Ibid Hal 192
}

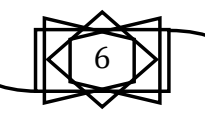


hukum adalah identik dengan norma-norma tertulis yang dibuat dan diundangkan oleh lembaga-lembaga atau pejabat berwenang. Sifat penelitian adalah deskriptif analitis yang bertujuan untuk menggambarkan, menginventarisir dan menganalisis teori-teori dan peraturan-peraturan yang berhubungan dengan permasalahan dalam penelitian ini. Sumber data yang digunakan adalah data primer yang didukung oleh data skunder. Teknik pengumpulan data sekunder pada penelitian ini menggunakan studi dokumen yaitu data yang diperoleh melalui penelusuran kepustakaan (library research) yang berupa data sekunder.

\section{Pembahasan}

\section{a. Latar belakang naskah akademik diperlukan dalam pembentukan peraturan perundang-undangan.}

Banyak aspek yang perlu dikaji dalam menyusun naskah akademik, salah satunya ialah harus dilakukannya riset mendalam dalam penyusunan naskah akademik peraturan. Selanjutnya, sebagai suatu hasil kajian yang bersifat akademik, tentu naskah akademik sesuai dengan prinsip-prinsip ilmu pengetahuan yang rasional, kritis, objektif, dan infersonal. Karena itu, pertimbangan-pertimbangan yang melatarbelakanginya tentulah berisi ide-ide normatif yang mengandung kebenaran ilmiah dan diharapkan terbebas dari kepentingan-kepentingan yang bersifat pribadi atau kelompok, kepentingan politik golongan, kepentingan politik kepartaian, dan sebagainya. ${ }^{18}$

Konsep judicial review berasal dari negara yang menganut supremasi konstitusi. Istilah judicial review itu sendiri merupakan istilah khas hukum tata negara Amerika Serikat yang artinya wewenang lembaga pengadilan untuk membatalkan setiap tindakan pemerintahan yang bertentangan dengan konstitusi. Menurut Soepomo, di Belanda mereka tidak mengenal Judicial review, mereka hanya mengenal hak menguji (toetsingenrecht). Judicial reviewmerupakan mekanisme pengujian peraturan perundang-undangan tertentu oleh hakim. Pengujian itu dilakukan atas suatu ketentuan peraturan perundang-undangan terhadap peraturan perundang-undangan yang lebih tinggi atau terhadap konstitusi sebagai hukum tertinggi. ${ }^{19}$

Sejarah panjang mengenai pengujian produk legislasi oleh sebuah lembaga peradilan akan terus berkembang. Pokok-pokok pemikiran John Marshall dan Hans Kelsen telah mempengaruhi cara berhukum di banyak negara. Indonesia sendiri kemudian mengimplementasikan konsep tersebut pada perubahan Undang-Undang Dasar ketiga tentang Mahkamah Konstitusi Republik Indonesia. ${ }^{20}$

Selain itu, dalam konteks peraturan daerah sedikitnya 1.501 Peraturan Daerah (Perda) yang dinilai memperpanjang rantai birokrasi dan menambah beban pungutan bagi investor telah dibatalkan oleh pemerintah pusat dalam rentang periode 20102014.Dari seluruh Perda yang dicabut itu, sebanyak 630 di antaranya merupakan perda yang berkaitan dengan pajak dan retribusi daerah yang berada dalam naungan

\footnotetext{
${ }^{18}$ Abdul Basyir, 2014, Jurnal Ius Vol II Nomor 5- Agustus 2014 hal.293,

${ }^{19} \mathrm{https} / / / \mathrm{www}$. google.com/, diakses pada tanggal 20 Mareat 2021 pukul 16.07 WIB

${ }^{20}$ Ibid
} 
UU Nomor 20 Tahun 2009 tentang Pajak Daerah dan Retribusi Daerah (PDRD) yang merevisi UU Nomor 34 Tahun 2000 dengan substansi yang serupa. ${ }^{21}$

Sehubungan dengan seringnya pembatalan terhadap perundang-undangan dan peraturan daerah, dijelaskan bahwa penggunaan Naskah Akademik dalam proses pembentukan peraturan daerah dapat meminimalisir terjadinya pembatalan peraturan daerah baik pada saat pemberlakuan peraturan daerah atau pada saat proses pembentukan peraturan daerah. ${ }^{22}$

Tingginya pembatalan peraturan perundang-undangan baik terhadap undangundang maupun peraturan daerah salah satunya disebabkan tidak adanya perencanaan dengan baik pada rancangan peraturan perundang-undangan berdasarkan kebutuhan yang dapat dipertanggungjawabkan secara ilmiah, bukan sekedar karena motif politik atau kepentingan lain yang sempit dan jangka pendek semata. Dalam pengertian lain, pembentukan undang-undang merupakan sebuah proses. Woodrow Wilson dalam bukunya "Congressional Government" mengatakan bahwa, legislation is an aggregate, not a simple production. Kemudian Jeremy Bentham dan John Austin mengatakan bahwa legislasi sebagai "any form of lawmaking". The term is, however restricted to a particuar form of law making, viz. The declaration in statutory form of rules of laws by the legislature of the state. The law that has it source in legislation is called enacted law or statute or written law". Dengan demikian bentuk peraturan yang ditetapkan oleh lembaga legislatif dengan maksud mengikat umum, dapat dikaitkan dengan pengertian "enacted law", "statute", atau undang-undang dalam arti luas. Dalam pengertian itu, legislasi merupakan proses pembentukan undang-undang. ${ }^{23}$

Pembentukan peraturan perundang-undangan meyangkut empat bentuk kegiatan, yaitu: pertama, prakarsa pembuatan undang-undang (legislation invitation), kedua, pembahasan rancangan undang-undang (law-making process),ketiga, persetujuan atas pengesahan undang-undang (law enactment approval), dan keempat, pemberian persetujuan pengikatan atau ratifikasi atas perjanjian atau persetujuan internasional dan dokumen-dokumen hukum yang mengikat lainnya (binding decision making on international agreement and treaties or other legal binding documents). ${ }^{24}$

Peraturan perundang-undangan menjadi instrumen untuk mewujudkan negara hukum. Peraturan perundangundangan merupakan instrumen yang menjadi acuan langsung dalam penegakan hukum dan tindakan-tindakan masyarakat yang membutuhkan hukum sebagai bagian dari masyarakan bernegara hukum. Peraturan perundang undangan sebagai cermin dari perwujudan konsep negara hukum yang telah diusung oleh pendiri Negara Kesatuan Republik Indonesia. Peraturan perundang-undangan diperlukan oleh masyarakat Indonesia karena peraturan perundang-undangan tersebut adalah aturan yang mampu menjamin kehidupan bernegara hukum bagi semua lapisan masyarakat. Tujuan utama pembentukan peraturan perundang-undangan bukan hanya menciptakan kodifikasi bagi normanorma dan nilai-nilai kehidupan

${ }^{21}$ http://www.kppod.org/index.php/en/berita/berita-media/407-1-501-perda-dibatalkan diakses pada tanggal 20 Maret 2021, Pukul 16.24 WIB

${ }^{22} \mathrm{http} / / /$ www.emakalah.com/2021/01/urgensi-naskah-akademik-dalam.html

23 Yuliandri. “Asas-Asas Pembentukan Peraturan Perundang-Undangan Yang Baik”.Jakarta: PT. Raja Grafindo Persada.2009, hal 15

${ }^{24}$ Ibid Hal 16

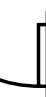




\section{b. Fungsi naskah akademik dalam pembentukan peraturan perundang- undangan.}

Naskah akademik masih bersifatfakultatif, terbatas pada beberapaperaturan perundang-undang sajapadahal melihat dari pada subtansinaskah akademik itu sendiri seharusnyadalam setiap pembentukan peraturan perundang-undagan harus dibuat naskah akademiknya. Hal ini sesuaidengan kesimpulan oleh Maria FaridaIndriani, tetang Naskah Akademik yaitu:

a. Bahwa keberadaan naskah akademik dalam penyusunanrancangan peraturan perundang-undanganbelum mempunyaikekuatan mengikat yang tegas, olehkarena kegunaan naskah akademikdalam penyusunan suatu rancanganperundang-undangan tidakmerupakan suatu keharusan bagidepartemen atau lembaga-lembagapemerintahan yang menjadipemrakarsa penyusunan rancanganperaturan perundang-undangan,demikian pula di lingkunganDewan Perwakilan Rakyat dan Dewan Perwakilan Daerah.

b. Bahwa selama ini suatu naskahakademik disusun berdasarkansuatu kebiasaan yang berlaku, olehkarena belum ada pedoman yangbaku, hal ini dapat dimengerti olehkarena naskah akademik bukanlahmerupakan suatu produk hukum.

c. Bahwa oleh karena secara definisi ditetapkan bahwa, naskah akademik adalah suatu naskah yang dapat dipertangungjawabkan secara ilmiah mengenai konsepsi yang berisi latar belakang, tujuan penyusunan, sasaran yang ingin diwujudkan dan lingkup,jangkauan, objek, atau arah pengaturan rancangan undangundangnya, penelitian, makanaskah akademik disusun sebelum rancangan undang-undang terbentuk. Hal ini disampaikan,oleh karena selama ini sering kali seseorang dimintakan untuk membuat suatu naskah akademik setelah rancangan undang-undangnyadirumuskan.

d. Bahwa untuk mengawasi apakah pembentukan peraturan perundang-undangan tersebut sesuai dengan yang direncanakan dan terumuskan dalam suatu naskah akademik, diperlukan pembentukan risalah pembahasan yang dilakukan selama proses pembentukan peraturan perundang-undangan tersebut berlangsung. ${ }^{25}$

Menurut Jimly Asshiddiqie,sebagai suatu hasil kajian yang bersifat akademik, tentu Naskah Akademik sesuai dengan prinsip-prinsip ilmu pengetahuan, yaitu: rasional, kritis, objektif, dan impersonal. Karena itu, pertimbangan-pertimbangan yang melatarbelakanginya tentulah berisi ide-ide normatif yang mengandung kebenaran ilmiah dan diharapkan terbebas dari kepentingan-kepentingan yang bersifat pribadi atau kelompok, kepentingan politik golongan, kepentingan politik kepartaian, dan sebagainya. Dengan Naskah Akademik, dapat dilihat bahwa setiap rancangan peraturan perundang-undangan tidak disusun karena kepentingan sesaat, kebutuhan yang mendadak, atau karena pemikiran yang tidak mendalam. Dalam praktik, kebutuhan seperti ini menyebabkan sebuah undang-undang lebih sering diubah dalam waktu singkat. ${ }^{26}$

Urgensi lain dari Naskah Akademik dalam proses pembuatan peraturan Naskah Akademik, bahwa Naskah Akademik memberikan pertimbangan dalam rangka pengambilan keputusan bagi pihak eksekutif dan legislatif mengenai pembentukan peraturan daerah tentang permasalahan yang dibahas dalam Naskah

${ }^{25}$ Maria Farida Indriani S, 2007, Ilmu Perundang-Undangan Proses dan TeknikPembentukannya, (Yogyakarta, Kansius). Hal. 248

${ }^{26}$ Jimly Asshiddidie, Perihal Undang-undang., op.cit, hal.320. 
Akademik. Sebuah Naskah Akademik juga memberikan saran-saran apakah semua materi yang dibahas dalam Naskah Akademik sebaiknya diatur dalam satu bentuk peraturan daerah atau ada sebagian yang sebaiknya dituangkan dalam peraturan pelaksana atau peraturan lainnya.

Saat ini ada kecenderungan pandangan dari masyarakat yang menempatkan peraturan perundang-undangan sebagai suatu produk yang berpihak pada kepentingan pemerintah (politik) semata sehingga dalam implementasinya masyarakat tidak terlalu merasa memiliki dan menjiwai perundang-undangan tersebut. Oleh karena itu Naskah Akademik diharapkan bisa digunakan sebagai instrumen penyaring, menjembatani dan upaya meminimalisir unsur-unsur kepentingan politik dari pihak pembentuk peraturan daerah, maksudnya adalah bahwa melalui Naskah Akademik yang proses pembuatannya dengan cara meneliti, menampung dan mengakomodasi secara ilmiah kebutuhan serta harapan masyarakat, maka mayarakat merasa memiliki dan menjiwai perundang-undangan tersebut.

Dalam proses pembuatan undang-undang baik yang melibatkan pihak legislatif maupun eksekutif ada juga hak yang dimiliki akademisi untuk membut suatu naskah akademik. Menurut Harry Alexander, yang dimaksud dengan naskah akademik adalah naskah awal yang memuat gagasan-gagasan peraturan dan materi muatan perundang-undangan bidang tertentu. Bentuk dan isi naskah akademik memuat gagasan peraturan suatu materi hukumbidang tertentu yag telah ditinjau secara holistik-futuristik dan dari berbagai aspek ilmu,dilengkapi dengan refensi memuat urgensi, konsepsi, landasan, alas hukum, prinsip-prinsip yang digunakan serta pemikiran-pemikiran tentang norma-norma yang telah dituangkan ke dalam bentuk pasal-pasal dengan mengajukan beberapa alternatif, yang disajikan dalam bentuk uraian yang sistematis dan dapat dipertanggung jawabkan secara ilmu hukum dan sesuai dengan politik hukum yang telah digariskan. ${ }^{27}$

Dari pendapat dan ketentuan tersebut, kalau dikupas lebih jauh menunjukkan bahwa pembutan naskah akademis tidak lebih dari sekedar upaya pendekatan menyeluruh (holistis) dari rencana pembuatan sebuah peraturan perundangundangan. Pendekatan ini dijalanan melalui sebuah metode riset sebagai langkah awal untuk mengetahui realitas kepentingan berbagai pihak baik pihak masyarakat maupun pihak pemegang hak legislasi (pemerintah dan parlemen). Namun, karena luasnya lingkup pendekatan, maka ada baiknya digunakan konsep dasar "tritunggal" dalam menelaah lahirnya sebuah peraturan perundag-undangan, yang meliputi aspek yuridis, sosiologis dan filosofis. Aspek yuridis, maksudnya agar produk hukum yang dilahirkan dapat berjalan sesuai dengan tujuan tanpa menimbulkan gejolak dimasyarakat; aspek sosiologis maksudnya, agar produk hukum yang diterbitkan tidak sampai bertentangan dengan nilai-nilai yang hidup di tengah-tengah

${ }^{27}$ Harry Alexander, 2004, Panduan Rancangan Undang-Undang di Indonesia, Jakarta XSYS Solusindo, Hal.120 


\section{FUNGSI NASKAH AKADEMIK DALAM PEMBENTUKAN}

PERATURAN PERUNDANG-UNDANGAN- Muhsin

masyarakat; aspek filosofis maksudnya, agar produk hukum yang diterbitkan jangan sampai bertentangan dengan nilai-nilai yang hakiki ditengah-tengah masyaarakat,misalnya agama.

Dengan batas jelas ini maka akan memudahkan untuk menginventarisasi seluruh bahan dan permasalahan yang muncul dilapangan. Dari ketiga aspek tersebut jugalah akan dijadikan rambu-rambu penting di dalam merumuskan batasan akademik dari naskah akademis yang akan dibuat tersebut. Hal ini penting untuk ditekankan agar naskah akademik yang dibuat tidak saja bertumpu pada keilmuan tetapi juga harus ditunjang dengan kenyataan sosial. Tumpuan keilmuan dibuat berdasarkan pada kaidah-kaidah dan teori pendapat para pakar (doktrin) sedangkan tumpuan kenyataan didasarkan pada kebutuhan nyata yang diinginkan masyarakat agar kehidupan terlindungi dan terjamin kepastian, kemanfaatan, dan keadilan hukum baik dimasa kini (das sein) maupun di masa depan (das solen futuristik).

Adanya Naskah Akademik sebagai suatu keharusan dalam proses pembentukan undang-undang, dikarenakan keberadaan Naskah Akademik sangat diperlukan dalam proses pembentukannya. Namun meskipun dalam pembentukan undang-undang naskah akademik menjadi suatu kewajiban tidak demikian untuk peraturan dibawahnya sepertihalnya perda. Meskipun dalam Undang-Undang Nomor 12 Tahun 2011 telah dimuatkan mengenai naskah akademik pembentukan perda tetapi ketentuan tersebut tidak sekuat seperti ketentuan yang tertuang dalam pembentukan undang-undang. Dalam undang-undang Nomor 12 Tahun 2011 naskah akademik belum menjadi keharusan dalam pembentukan perda. Dalam naskah akademik memaparkan alasan-alasan, fakta atau latar belakang tentang hal-hal yang mendorong disusunnya suatu masalah atau urusan sehingga dipandang sangat penting dan mendesak diatur dalam peraturan daerah. Manfaat dari data atau informasi yangdituangkan dalam latar belakang bagi pembentuk peraturan daerah itu adalah bahwa mereka dapat mengetahui dengan pasti tentang mengapa perlunya dibuat sebuah peraturan daerah dan apakah peraturan daerah tersebut memang diperlukan oleh masyarakat.

Pemikiran tentang pentingnya Naskah Akademik ini setidaknya dilatarbelakangi oleh dua alasan, yaitu alasan substantif dan alasan teknis. Alasan substantif dimaksudkan untuk memperoleh rancangan peraturan yang baik, aplikatif dan futuristik. Selain itu, ketika suatu rancangan peraturan sudah didukung oleh Naskah Akademik yang memadai, maka perdebatan dalam pembahasan rancangan peraturan di lembaga legislatif dapat lebih efisien. Karena seringkali perdebatan terjadi terhadap masalah yang seharusnya telah dijawab dalam Naskah Akademik. Sedangkan alasan teknisnya dimaksudkan untuk membatasi daftar prioritas yang terlalu banyak namun tidak didukung dokumen yang memadai. ${ }^{28}$

Pengertian yang diberikan oleh Pasal 1 angka (11) Undang-Undang Nomor 12 Tahun 2011 tentang Pembentukan Peraturan Perundang-Undangan menandakan bahwa naskah akademik telah ditetapkan secara tegas sebagai bagian dari undangundang tersebut yang memberikan gambaran bahwa naskah akademik memiliki kedudukan tersendiri dalam undang-undang tersebut. Naskah akademik merupakan salah satu proses dalam pembuatan peraturan perundang-undangan terutama dalam

${ }^{28}$ Jazim Hamidi dan Kemilau Mutik, 2011, Legislative Drafting, (Yogyakarta: Total Media), Hal. $35-36$. 
pembuatan Rancangan undang-undang dan rancangan peraturan daerah, dimana naskah akademik harus dilampirkan dalam Rancangan undang-undang meskipun dalam Rancangan peraturan daerah masih bersifat fakultatif karena dapat disertai penjelasan atau keterangan. ${ }^{29}$

Naskah akademik dalam peraturan daerah baik peraturan daerah provinsi dan peraturan daerah kabupaten/ kota sudah diatur dalam Undang-Undang nomor 12 Tahun 2011 tentang Pembentukan Peraturan Perundang-undangan (UU 12 Tahun 2011). Dalam Pasal 56 ayat (2) UU 12 Tahun 2011 disebutkan bahwa rancangan Peraturan Daerah Provinsi sebagaimana dimaksud pada ayat (1) disertai dengan penjelasan atau keterangan dan/atau Naskah Akademik.

Penggunaan kata "disertai" dalam pembentukan Peraturan Daerah bisa saja dimaknai di satu sisi sebagai keharusan dan di sisi lain sebagai kebolehan untuk tidak menyertakan Naskah Akademik. Semestinya sebelum kata "disertai" hendaknya ada kata "dapat" atau "harus" sehingga tidak menimbulkan multi tafsir atau kekaburan norma mengenai perlu tidaknya penyusunan Naskah Akademik dalam pembentukan Peraturan Daerah. ${ }^{30}$

Terbitnya Undang-Undang Nomor 12 Tahun 2011 tentang tentang Pembentukan Peraturan Perundang-Undangan membawa paradigma yang mendorong pembentukan peraturan perundang-undangan lebih demokratis, terencan, terpadu dan berkelanjutan dalam perspektif hukum nasional yang didasarkan prinsip Negara hukum demokratis (democratische rechtsstaat) sinyalsinyal paradigma di atas tercermin antara lain dalam penguatan pasal-pasal menyangkut materi muatan, perencanaan peraturan perundang-undangan, penyebarluasan peraturan perundang-undangan, partisipasi masyarakat dan kewajiban menyertakan naskah akademik. ${ }^{31}$

Adanya Naskah Akademik sebagai suatu keharusan dalam proses pembentukan undang-undang, dikarenakan keberadaan Naskah Akademik sangat diperlukan dalam proses pembentukannya. Namun meskipun dalam pembentukan undang-undang naskah akademik menjadi suatu kewajiban tidak demikian untuk peraturan dibawahnya sepertihalnya perda. Meskipun dalam Undang-Undang Nomor 12 Tahun 2011 telah dimuatkan mengenai naskah akademik pembentukan perda tetapi ketentuan tersebut tidak sekuat seperti ketentuan yang tertuang dalam pembentukan undang-undang. Dalam undang-undang No. 12 Tahun 2011 naskah akademik belum menjadi keharusan dalam pembentukan perda. Dalam naskah akademik memaparkan alasan-alasan, fakta atau latar belakang tentang hal-hal yang mendorong disusunnya suatu masalah atau urusan sehingga dipandang sangat penting dan mendesak diatur dalam peraturan daerah. Manfaat dari data atau informasi yang dituangkan dalam latar belakang bagi pembentuk peraturan daerah itu adalah bahwa mereka dapat mengetahui dengan pasti tentang mengapa perlunya

\footnotetext{
${ }^{29}$ Gunawan, Kedudukan dan Urgensi Naskah Akademik dalam Pembentukan Peraturan Daerah Di Tinjau Dari Undang-Undang Nomor 12 Tahun 2012 tentang Pembentukan Peraturan Perundang-Undang,

${ }^{30}$ Abdul Basyir, 2014, Jurnal Ius Vol II Nomor 5- Agustus 2014 hal.285-306,

${ }^{31}$ R. Muhamad Mihradi, Republik Tanpa Publik Pasca Reformasi (Retaknya Relasi Negara, Hukum dan Demokrasi),(Bogor: Pusat Studi Hukum dan Demokrasi Fakultas Hukum Universitas Pakuan, 2012), Hal., 117-118.
} 
dibuat sebuah peraturan daerah dan apakah peraturan daerah tersebut memang diperlukan oleh masyarakat. ${ }^{32}$

Sebagaimana telah dikemukakan sebelumnya, adanya Naskah Akademik bukan sebagai suatu keharusan dalam proses pembentukan peraturan daerah, akan tetapi keberadaan Naskah Akademik sangat diperlukan dalam proses pembentukan peraturan daerah. Naskah Akademik memaparkan alasan-alasan, fakta atau latar belakang tentang hal-hal yang mendorong disusunnya suatu masalah atau urusan sehingga dipandang sangat penting dan mendesak diatur dalam peraturan daerah. Manfaat dari data atau informasi yang dituangkan dalam latar belakang bagi pembentuk peraturan daerah itu adalah bahwa mereka dapat mengetahui dengan pasti tentang mengapa perlunya dibuat sebuah peraturan daerah dan apakah peraturan daerah tersebut memang diperlukan oleh masyarakat. ${ }^{33}$

Umumnya, teori-teori perundang-undangan hanya menyebutkan tiga aspek kajian untuk mengukur baik-tidaknya suatu peraturan perundang-undangan, yaitu dari aspek filosofis, yuridis, dan sosiologis. Akan tetapi, sebuah peraturan perundangundangan (termasuk peraturan daerah) tidak bisa sama sekali dilepaskan dari unsurunsur politis dalam pembentukannya. Aspek politis pada dasarnya mengedepankan persoalan tarik-ulur kepentingan antara pemerintah dan masyarakat. Dalam Naskah Akademik pun kajian terhadap aspek ini perlu dilakukan. Bagaimana sesungguhnya kemauan politik dari pemerintah, dan bagaimana bargaining power dari kemauan politik pemerintah ini ketika berhadapan dengan kepentingan masyarakat, terutama dalam era demokrasi seperti saat ini. ${ }^{34}$

Tidak kurang pentingnya juga kajian-kajian dari berbagai aspek terkait, antara lain, dari aspek ekonomi dan ekologi, yang akan lebih memperkaya Naskah Akademik dan pada tahap selanjutnya juga akan lebih menyempurnakan substansi peraturan perundang-undangan (peraturan daerah) yang akan dibuat. Jika kondisi memungkinkan maka sesungguhnya proses pembentukan peraturan perundangundangan (termasuk peraturan daerah) perlu menggunakan apa yang disebut proses regulatory impact assessment/Analysis (RIA), yang berguna untuk mengetahui sejauhmana dampak ekonomis yang timbul dari peraturan tersebut bila sudah terbentuk dan diberlakukan di tengah-tengah masyarakat. ${ }^{35}$

Regulatory Impact Analysis(RIA) adalah suatu alat yang fundamental untuk membantu pemerintah untuk menilai dampak dari sebuah regulasi. RIA digunakan untuk menguji dan mengukur kemungkinan manfaat, biaya dan dampak peraturan baru atau yang sudah ada. Pelaksanaan RIA mendukungproses pembuatan kebijakan dengan ikut serta data empiris yang berharga untuksebuah keputusan kebijakan, dan melalui pembangunan kerangka keputusan yangrasional untuk memeriksa potensi implikasi dari pilihan kebijakan peraturan. Ini merupakan faktor penting dalam menanggapi dampak ekonomi modern terbukapasar internasional dan keterbatasan anggaran, dan konsekuensi dari tuntutan kebijakan yang saling bersaing. Fitur utama

\footnotetext{
${ }^{32}$ Gunawan, Kedudukan dan Urgensi Naskah Akademik dalam Pembentukan Peraturan Daerah Di Tinjau Dari Undang-Undang Nomor 12 Tahun 2012 tentang Pembentukan Peraturan Perundang-Undang.

${ }_{34}^{33}$ Rusdiato, Naskah Akademik Dalam Pembentukan Peraturan Perundang-Undangan,

${ }^{35}$ Ibid Hal 10
} 
dari RIA adalah pertimbangan potensi dampak ekonomi dari sebuah peraturan/regulasi. ${ }^{36}$

Tujuan dari RIA adalah untuk menyediakan secara terperinci dan sistematis penilaian potensi dampak dari peraturan baru untuk menilai apakah kemungkinan peraturan untuk mencapai tujuan yang diinginkan. Kebutuhan untuk RIA muncul dari fakta bahwa regulasi umumnya memiliki banyak dampak dan bahwa ini sering sulit untuk meramalkan tanpa studi yang rinci dan konsultasi dengan pihak-pihak yang terkena dampak. Pendekatan ekonomi masalah peraturan juga menekankan risiko tinggi yang biaya peraturan dapat melebihi manfaat. Dari perspektif ini, tujuan utama dari RIA adalah untuk memastikan bahwa peraturan akan meningkatkan kesejahteraan masyarakat dari sudut pandang yaitu, bahwa keuntungan akan melebihi biaya. RIA umumnya dilakukan dalam konteks komparatif, dengan berbagai sarana untuk mencapai tujuan dicari yang dianalisis dan hasilnya dibandingkan. ${ }^{37}$

Adapun tahapan dalam proses perancangan RIA, secara sistematis dalam menganalisis serta mengkomunikasikan dampak yang ada dari peraturan baru berdasarkan versiOrganisation for Economic Co-Operation and Developement(OECD) 2008, yaitu :38

1. Definisi/Definition (policy objective, policy context). Definisi konteks kebijakan dan tujuan, khususnya identifikasi sistematik dari masalah yang menyediakan dasar bagi tindakan oleh pemerintah.

2. Identifikasi /Identification (regulatory options). Identifikasi dan definisi dari semua kemungkinan peraturan dan non-peraturan pilihan yang akan mencapai tujuan kebijakan.

3. Penilaian/Assesment (cost, benefit, other impact). Identifikasi dan kuantifikasi dampak pilihan yang dipertimbangkan, termasuk biaya,manfaat dan efek distribusi.

4. Konsultasi /Consultation (involving stakeholders). Konsultasi publik yang didirikan secara sistematis untuk memberikan kesempatan bagi seluruh stakeholders untuk berpartisipasi dalam proses pengawasan. Ini memberikan informasi penting mengenai biaya dan manfaat dari alternatif, termasuk efektivitas mereka. Konsultasi untuk memperoleh alternatif yang terbaik dengan melibatkan stakeholders(involving stakeholders), Konsultasi ini harus dilakukan mulai dai tahap awal perumusan regulasi sampai dengan tahap implementasi dan monitoring pelaksanaan regulasi. Dalam metode RIA, komunikasi untuk konsultasi sudah mulai dilakukan dalam tahap perumusan masalah. Konsultasi pada tahap ini untuk memastikan bahwa pemerintah menangani masalah yang tepat, dan bahwa persepsi pemerintah terhadap masalah yang dihadapi sama dengan persepsi masyarakat, industri, maupun stakeholders lainnya. Konsultasi pada tahap pengembangan alternatif terutama bertujuan untuk mendapatkan masukan mengenai opsi yang dapat dipilih, dan untuk menguji apakah opsi tersebut dapat dijalankan dengan baik(workable). Dalam tahap analisis cost \& benefit, konsultasi terutama bertujuan untuk mendapatkan masukan mengenai biaya(kerugian/kesulitan) dan manfaat(keuntungan) dari setiap opsi, dan untuk

36 http://mte.pasca.mercubuana.ac.id/wpcontent/uploads/2021/04/17_jurnal_wawan_01-20.pdf diakses pada tanggal 17 April 2021 pukul 21.50 WIB

${ }^{37}$ Ibid 
mendapatkan konfirmasi apakah apakah biaya/manfaat yang diharapkan benarbenar terwujud dalam praktiknya.

Naskah Akademik juga memberikan ruang bagi para pengambil keputusan yang berwenang untuk membahas dan menetapkan peraturan daerah (baik pemerintah daerah maupun Dewan perwakilan Rakyat Daerah) untuk mempertimbangan apakah suabtsnasi/materi yang terkandung dalam Naskah Akademik itu layak diatur dalam bentuk peraturan daerah atau tidak, dan apakah hanya perlu satu peraturan daerah atau dimungkinkan untuk dituangkan dalam lebih dari satu peraturan (mungkin peraturan sederajat atau peraturan pelaksanaan).

Saat ini ada tendensi pandangan masyarakat bahwa peraturan perundangundangan (termasuk peraturan daerah) adalah produk yang selalu berpihak pada kepentingan pemerintah (politik) semata-mata, sehingga dalam pelaksanaannya masyarakat tidak terlalu merasa memiliki dan menjiwai peraturan perundangundangan terkait. Oleh karena itu, Naskah Akademik diharapkan dapat digunakan sebagai instrumen penyaring, menjembatani, dan meminimalisir unsur-unsur kepentingan politik dari pembentuk peraturan perundang-undangan (peraturan daerah). Naskah Akademik menjelaskan objektivitas tujuan dibentuknya peraturan perundang-undangan, karena didasarkan atas hasil kajian dan/atau penelitian, yang menampung aspirasi serta mengakomodasi kepentingan dan keinginan masyarakat, serta didukung oleh kebijakan politik dan peraturan perundang-undangan. ${ }^{39}$

\section{Kesimpulan}

Berdasarkan uraian pada bab-bab diatas, maka dapat diambil kesimpulan dalam penelitian ini:

a. Berdasarkan penelitian yang dilakukan penulis, ada beberapa alasan yang melatarbelakangi mengapa naskah akademik dibutuhkan dalam pembentukan peraturan perundang-undangan. Alasan-alasan tersebut adalah pertama, tujuan hukum (peraturan) itu sendiri, dimana salah satu tujuannya adalah bahwa suatu peraturan harus berguna dan menimbulkan kebaikan bagi masyarakat. Kedua, demi tercapaiya asas-asas pembentukan peraturan perundang-undangan yang baik. Ketiga, efektivitas peraturan perundang-undangan dimasyarakat, dimana suatu peraturan itu harus berlaku dan dapat diterapkan dalam masyarakat. Keempat, supaya peraturan perundang-undangan tidak di uji materil (judicial review) karena peraturan perundang-undangan tersebut tidak relevan atau bertentangan dengan peraturan perundang-undangan yang lebih tinggi. Kelima, bahwa naskah akademik itu merupakan bagian dari pembentukan peraturan perundang-undangan, maka naskah akademik wajib disertakan dalam pembentukan peraturan perundang-undangan.

b. Naskah akdemik berfungsi sebagai naskah ilmiah yang dapat dipertanggungjawabkan yang berisi latar belakang, tujuan penyusunan, sasaran yang ingin diwujudkan sehingga penting dan mendesak untuk disusun suatu peraturan perundang-undangan. Naskah Akademik juga memberikan gambaran mengenai substansi, materi dan ruang lingkup dari sebuah peraturan perundangundangan yang akan dibuat. Dalam hal ini dijelaskan mengenai konsepsi, pendekatan dan asas-asas dari materi hukum yang perlu diatur, serta pemikiran-

\footnotetext{
${ }^{39}$ Ibid Hal 11
} 
pemikiran normanya. Naskah Akademik juga memberikan pertimbangan dalam rangka pengambilan keputusan bagi pihak eksekutif dan legislatif pembentukan peraturan perundang-undangan tentang permasalahan yang akan dibahas dalam naskah akademik. 


\section{Daftar Pustaka}

Abdul Basyir, 2014, Jurnal Ius Vol II Nomor 5- Agustus 2014

Benediktus Hestu CiptoHandoyo, Prinsip-Prinsip Legal Drafting dan Naskah Akademik,(Yogyakarta, : Cahaya Atma Pustaka, 2014).

Gunawan, Kedudukan dan Urgensi Naskah Akademik dalam Pembentukan

Peraturan Daerah Di Tinjau Dari Undang-Undang Nomor 12 Tahun 2012 tentang Pembentukan Peraturan Perundang-Undang,

H. A. S. Natabaya, Manifestasi Nilai-Nilai Dasar Dalam Peraturan PerundangUndangan, Jurnal Konstitusi, (Volume 3 Nomor 2, Mei 2006), Mahkamah Konstitusi Republik Indonesia, 2006.

Harry Alexander, 2004, Panduan Rancangan Undang-Undang di Indonesia, Jakarta XSYS Solusindo.

Jazim Hamidi dan Kemilau Mutik, 2011, Legislative Drafting, (Yogyakarta: Total Media).

Maria Farida Indrati S, Ilmu Perundang-Undangan, Proses dan Teknik Pembentukannya, buku 2, (Yogyakarta :, kanisius, 2007).

Jimly Asshidiqie (I), Implikasi Perubahan UUD 1945 Terhadap Pembangunan Hukum Nasional, (Jakarta, Mahkamah Konstitusi Republik Indonesia, 2005)

Jimly Asshidiqie (III), Konstitusi dan Konstitusionalisme (Jakarta: Konstitusi Pers, 2005)

Jimly Asshidiqie (IV), Perihal Undang-Undang di Indonesia, (Jakarta, : Sekretariat Jenderal dan Kepaniteraan Mahkamah Konstitusi RI, 2006).

Rachmat Trijono, Dasar-Dasar Ilmu Pengetahuan Perundang-Undangan, ( Jakarta :, Papas Sinar Sinanti, 2013).

R. Muhamad Mihradi, Republik Tanpa Publik Pasca Reformasi (Retaknya Relasi Negara, Hukum dan Demokrasi) ,(Bogor: Pusat Studi Hukum dan Demokrasi Fakultas Hukum Universitas Pakuan, 2012).

Undangan,

Rusdiato, Naskah Akademik Dalam Pembentukan Peraturan Perundang-

Yuliandri, Asas-Asas Pembentukan Peraturan Perundang-Undangan Yang Baik, (Jakarta, : PT. Raja Grafindo Persada, 2009)

Undang-Undang Nomor 12 tahun 2011 Tentang Pembentukan Peraturan Perundang-Undangan.

http://mte.pasca.mercubuana.ac.id/wpcontent/uploads/2010/09/01_jurnal_ wawan_01-20.pdf diakses pada tanggal 17 April 2021 pukul 21.50 WIB

https://www.google.com/, diakses pada tanggal 20 Mareat 2021 pukul 16.07 WIB

http://www.kppod.org/index.php/en/berita/berita-media/407-1-501-perdadibatalkan diakses pada tanggal 20 Maret 2021, Pukul 16.24 WIB http://www.emakalah.com/2021/01/urgensi-naskah-akademik-dalam.html 